\title{
Novel Morphogenesis in Ax-3, a Mutant Strain of the Cellular Slime Mould Dictyostelium discoideum
}

\author{
By ROBERT L. CLARK, ${ }^{\dagger}$ GREGORY S. RETZINGER \\ AND THEODORE L. STECK \\ Departments of Biochemistry and Medicine, The University of Chicago, \\ 920 East 58th Street, Chicago, Illinois 60637, U.S.A.
}

(Received 8 April 1980)

\begin{abstract}
The cellular slime mould Dictyostelium discoideum constructs a succession of characteristic structures (grexes) in the multicellular phase of its life cycle. Compared with the wild-type strain, NC-4, grexes of a mutant strain, Ax-3, exhibited a profound prolongation of the early mound stage of development and a premature and exaggerated tendency to construct short, broad and bulbous forms. The aberrant Ax-3 phenotype was partially corrected by increasing the temperature of development, decreasing the plating density, perfusing with fresh air, or by introducing $0 \cdot 1 \mathrm{~mm}$-formycin B or 3-deazaadenosine into the agar. Mixtures of NC-4 and Ax-3 formed hybrid grexes which often became transformed into toruses by spiral centrifugal movement of the cells. Under other conditions, hybrid mounds developed into binary grex structures, cylindrical columns on top of hemispherical mounds, each component of which completed the morphogenetic sequence independently. The narrow upper structure appeared to be composed primarily of NC-4 cells. These novel patterns of morphogenesis support our hypothesis that the shape of the organism is controlled by the specification of the circumference of loops of cells within the grex.
\end{abstract}

\section{INTRODUCTION}

Morphogenesis, the shaping of cells and tissues, is one manifestation of development whose mechanisms are largely unknown. A favourable system for the study of morphogenesis is the simple eukaryote, the cellular slime mould, and particularly Dictyostelium discoideum. Amoebae of this organism respond to starvation by aggregating into a succession of multicellular structures, called grexes. The initial aggregate elongates into a migratory slug which ultimately culminates its developmental cycle by forming a fruiting body (see Bonner, 1967; Loomis, 1975).

We became interested in Ax-3, a mutant strain of $D$. discoideum selected by Loomis (1971) for its ability to grow on axenic media, when we observed that it formed plaques in a lawn of bacteria that were different from those of NC-4, the parental wild-type strain. Our initial intent was to use this differential plaque morphology as a marker in cell sorting experiments. However, in control experiments in which NC-4 and Ax-3 cells were labelled with different fluorochromes and then mixed, fluorescence microscopy revealed that the resultant grexes had a core of NC-4 cells within a cortex of Ax-3 cells. Thus, the genetic marker was not neutral with respect to sorting out. However, this finding did stimulate further interest in $\mathrm{Ax}-3$, and we found that $\mathrm{Ax}-3$ exhibited unusual morphogenetic forms, particularly when mixed with NC-4. The rotating toruses and other shapes that we observed contributed to our hypothesis that morphogenesis in this species employs the programmed

$\dagger$ Present address: Division of Fetal Pharmacology, Children's Hospital Research Foundation, Elland and Bethesda Avenue, Cincinnati, Ohio 45229, U.S.A. 
specification of the circumferences of grex structures (Clark \& Steck, 1979). We now report our observations of Ax-3 and Ax-3/NC-4 mixtures, all of which support this hypothesis.

\section{METHODS}

Organisms. Dictyostelium discoideum Raper, strain NC-4, and Enterobacter aerogenes (stock numbers 11735 and 13048, respectively) were obtained from the American Type Culture Collection. Dictyostelium discoideum, strain Ax-3, obtained from W. C. Summers of Yale University, was originally selected by W. F. Loomis (1971).

Materials. Nutrients and agar were from Difco. Formycin B was from Calbiochem. 3-Deazaadenosine was a generous gift from Peter K. Chiang and Giulio L. Cantoni. Nutrient-free buffer (NFB) contained, per litre, $2.31 \mathrm{~g} \mathrm{KH}_{2} \mathrm{PO}_{4}, 1.00 \mathrm{~g} \mathrm{~K}_{2} \mathrm{HPO}_{4}$ and $0.5 \mathrm{~g} \mathrm{MgSO}_{4} .7 \mathrm{H}_{2} \mathrm{O}$. Bacterial growth medium contained, per litre NFB, $5.0 \mathrm{~g}$ glucose, 5.0 g Bacto-peptone, and 0.5 g yeast extract (Sussman, 1961). Nutrient-free agar plates (Falcon 1001 or 1007) contained a $4 \mathrm{~mm}$ layer of $2 \%(\mathrm{w} / \mathrm{v}$ ) agar in NFB. Nutrient agar plates (Falcon 1001) contained $2 \%(\mathrm{w} / \mathrm{v})$ agar in bacterial growth medium. Axenic medium (HL-5) contained, per litre, $10 \mathrm{~g}$ glucose, $10 \mathrm{~g}$ proteose peptone no. $3,5 \mathrm{~g}$ yeast extract, $0.965 \mathrm{~g} \mathrm{Na}_{2} \mathrm{HPO}_{4} .7 \mathrm{H}_{2} \mathrm{O}, 0.486 \mathrm{~g} \mathrm{KH}_{2} \mathrm{PO}_{4}, 100000$ units penicillin and 0.1 g streptomycin (Loomis, 1971).

Growth conditions. All procedures were carried out at room temperature, and all growing or developing cells were incubated in the dark at $22^{\circ} \mathrm{C}$ unless otherwise specified. Cell counts were performed with a model $Z_{\mathrm{B}}$ Coulter counter. To propagate NC-4 cells, spores were harvested from fruiting bodies and mixed with $0.2 \mathrm{ml}$ of a 1 to $2 \mathrm{~d}$ culture of $E$. aerogenes in bacterial growth medium. A sample was spread evenly on nutrient agar plates with a glass rod. Plating densities were calculated from measured doubling times [3.9 $\pm 0.5 \mathrm{~h}$ (s.D.) for NC-4 and $6.4 \pm 1.3 \mathrm{~h}$ (S.D.) for Ax-3] so that the yield was $5 \times 10^{7} \mathrm{NC}-4$ cells per plate and $2 \times 10^{7} \mathrm{Ax}-3$ cells per plate after $24 \mathrm{~h}$ incubation.

Strain Ax-3 was also grown in $100 \mathrm{ml}$ axenic medium in $250 \mathrm{ml}$ conical flasks, swirled at $225 \mathrm{rev} \cdot \mathrm{min}^{-1}$ (radius of gyration, $1.0 \mathrm{~cm}$ ). Cells were routinely passaged every 2 to $3 \mathrm{~d}$ before the culture reached a density of $5 \times 10^{8}$ cells ml-1. During the 10 weeks after starting suspension cultures from stocks of frozen Ax-3 spores, the mean and mode of the doubling time were both $10.3 \mathrm{~h}$. The doubling time declined during axenic culture; cultures were restarted from frozen spores either after 10 weeks or when the doubling time dropped below $9 \mathrm{~h}$. We routinely harvested Ax-3 cells at a density of $5 \times 10^{6}$ cells ml-1, at which approximately $98 \%$ of the cells entered aggregates.

Conditions for morphogenesis. Because experimental variables, such as substratum moisture, light and ventilation, dramatically influenced the developmental pattern, we carefully standardized our conditions (particularly the preparation of nutrient-free agar plates). These plates were poured the day before use and stored at room temperature in an air-tight box with humidity maintained by a beaker of water. An hour before use, the lids of the plates were removed, and the plates and lids were dried for $40 \mathrm{~min}$ in an incubator at 48 to $52{ }^{\circ} \mathrm{C}$. The lids were replaced and the plates were allowed to cool.

Differentiation was initiated as follows. Strain NC-4 amoebae and bacteria were removed from nutrient agar plates in two $10 \mathrm{ml}$ portions of ice-cold NFB. The amoebae were washed free of bacteria with chilled NFB by three centrifugation cycles of $455 \mathrm{~g}$ for $2.5 \mathrm{~min}$. Strain Ax-3 amoebae, grown axenically, were similarly washed twice with ice-cold NFB. Cell pellets were resuspended in chilled NFB and applied at $0.01 \mathrm{ml}$ $\mathrm{cm}^{-2}$ to pre-dried nutrient-free agar plates, usually at a density of $10^{6} \mathrm{cells} \mathrm{cm}^{-2}$. Alternatively, cells were spread on Millipore filters (HABP047SO) or Whatman 50 filters on Millipore absorbent pads (AP10047SO) or nutrient-free agar plates (Sussman, 1966). The cells were spread evenly, first with the heel of a bent glass rod, then by shaking and swirling the plates. The washing procedure took approximately $45 \mathrm{~min}$; the time when the cells were spread was taken as the onset of morphogenetic development.

Examination and photography of specimens. Microscopic examination of organisms from the side was performed in plastic chambers such that the plane of the agar substratum was angled $75^{\circ}$ or $90^{\circ}$ to the horizontal. Rectangular sections of agar or filter paper/pad assemblies were transferred from Petri dishes to the chambers $30 \mathrm{~min}$ after depositing the cells.

Because of the sensitivity of slime mould development to light (see Newell et al., 1969, and Results), observations were made on replicate plates or chambers, each of which was viewed only once. Morphogenesis in Petri plates and in chambers was also recorded by time-lapse cinemicrography, during which the organisms were exposed only to the low levels of illumination (approximately $20 \mathrm{ft}$-candles, $220 \mathrm{~lx}$ ) required for filming. We varied the developmental temperature during photography by placing the specimen in a glass-bottomed water bath regulated with water circulating through a coil of copper tubing. 


\section{RESULTS}

There are numerous classical accounts of the morphogenesis of $D$. discoideum (Raper, 1935, 1940a, b; Raper \& Fennell, 1952; Bonner, 1944, 1952; Shaffer, 1962), but for comparison with the mutant strain Ax-3 (Fig. 2), we give here a description of the parent strain, NC-4, under standardized conditions (Fig. 1).

\section{Morphogenesis of $\mathrm{NC}-4$}

Starvation on nutrient-free agar plates induced the development of aggregation centres beginning at 9 to $12 \mathrm{~h}$ and ending asynchronously between 17 and $20 \mathrm{~h}$ of development. A conical vertical protrusion, the papilla, promptly appeared in the centre of the growing aggregate (Fig. 1 A), establishing an axis of symmetry which was the dominant organizational feature in all subsequent multicellular forms. The grexes elongated and narrowed to form cylinders which then reclined to the horizontal (Fig. 1B, C, D). As the resultant slug migrated, its anterior portion continually bobbed up and down, as also noted by Francis (1962) (Fig. 1E, F).

During the final ascent of the tip toward a vertical orientation, the posterior cell mass expanded beneath it (Fig. 1 G, H). This marked the beginning of culmination (i.e. the stages leading directly to fruiting body formation). The shortened axis, widened and rounded posterior cell mass, and moat-like depression around the central papilla made this grex stage resemble a sombrero (Fig. 1I).

Finally, stalk elongation lifted the peripheral cell mass off the substratum (Fig. $1 \mathrm{~J}, \mathrm{~K}, \mathrm{~L}$ ), eventually producing the mature fruiting body (Fig. $1 \mathrm{M}, \mathrm{N}, \mathrm{O}$ ). Culmination typically lasted approximately $5 \mathrm{~h}$.

\section{Morphogenesis of Ax-3}

Strain Ax-3 exhibited a distinctively altered phenotype which was enhanced by growth in axenic culture. Ax-3 aggregation commenced after 6 to $8 \mathrm{~h}$ of development and was completed by 10 to $12 \mathrm{~h}$ with the formation of hemispherical mounds (Fig. 2A). The area from which an aggregation centre recruited cells (the territory) was much smaller for Ax-3 $\left[1.37 \pm 0.16 \mathrm{~mm}^{2}\right.$ (S.E.M.)] than for NC-4 [2.86 $\pm 0.18 \mathrm{~mm}^{2}$ (S.E.M.)]. The mounds then became flattened and some acquired a central depression not seen in NC-4 (Fig. 2B). Thus, Ax-3 completed aggregation sooner than NC-4 and before the formation of a papilla.

After a delay of $5 \mathrm{~h}$ or more, the bases of the grexes became constricted and papillae emerged rather synchronously as broad, often eccentric caps (Fig. 2D, E). As the Ax-3 grexes elongated, a stalk-like projection appeared at the base making these grexes resemble bowling pins (Fig. 2F, G, H). Reclining Ax-3 grexes were initially bulbous (Fig. 2I) but those that migrated eventually became cylindrical (Fig. 2J). Even the most cylindrical Ax-3 slugs, however, continued to be broader than those of NC-4. Thus, elongating Ax-3 grexes were broader and more bulbous than NC-4 grexes.

Fruiting in Ax-3 was more synchronous than in NC-4 and occurred after a much shorter period of slug migration ( 0 to $0.3 \mathrm{~d})$ compared with $\mathrm{NC}-4(0.5$ to $2 \mathrm{~d})$. At the time of culmination, Ax-3 came to resemble NC-4 in both its proportions and size (Fig. $2 \mathrm{~K}$ to $\mathrm{P}$ ).

\section{Dependence of the Ax-3 phenotype on experimental variables}

The pattern of NC-4 and Ax-3 development varied characteristically with experimental manipulation, demonstrating the conditionality of these phenotypes. It appeared that the patterns exhibited by $\mathrm{NC}-4$ and $\mathrm{Ax}-3$ under standard conditions represented alternative modes of expression of the same morphogenetic programme, since the following changes in the environment could shift the NC-4 development toward the Ax-3 phenotype and vice versa.

Temperature. The development of NC-4 and Ax-3 grexes exhibited differential tempera- 

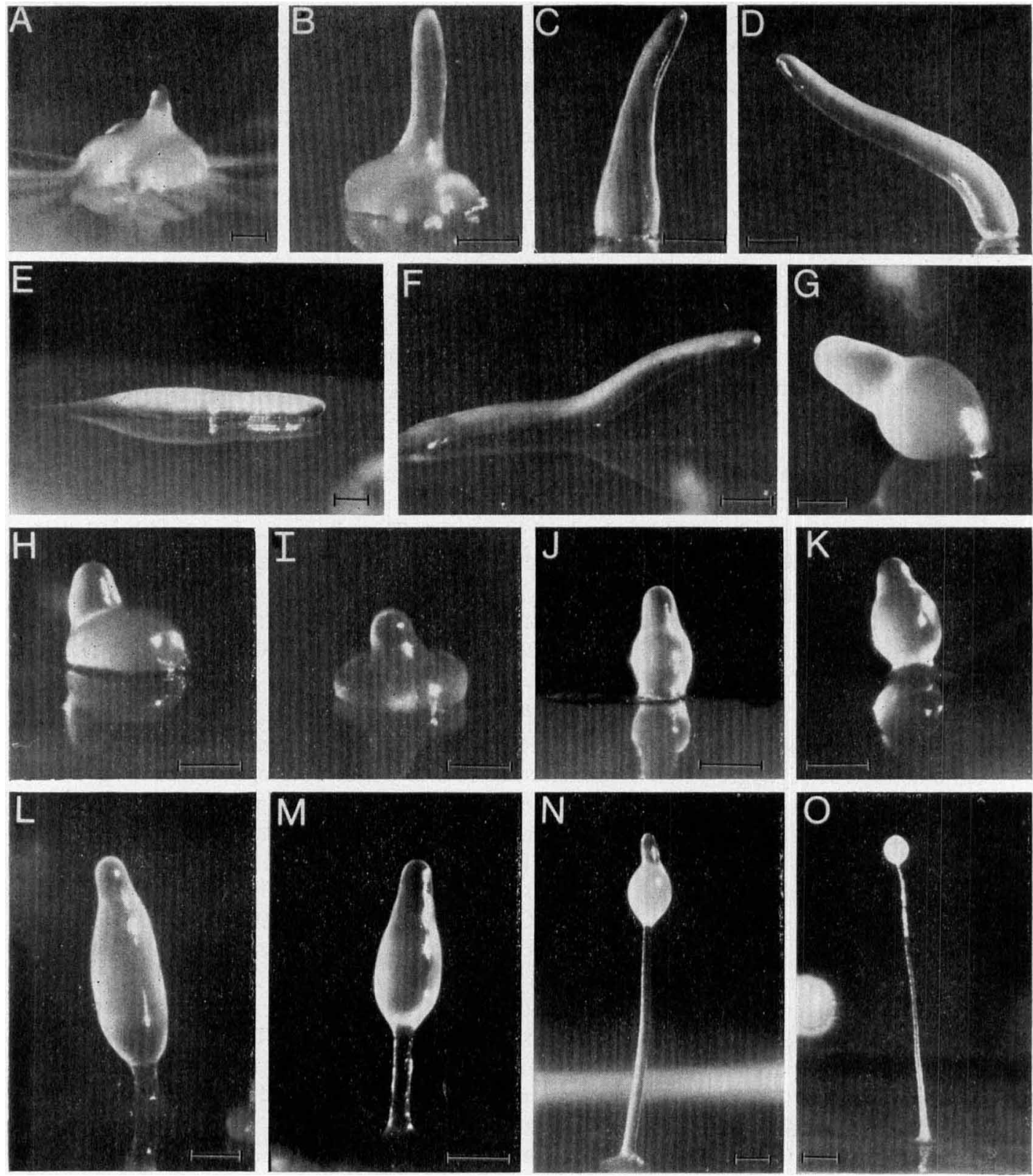

Fig. 1. Stages in the morphogenesis of the wild-type strain, NC-4. The temporal sequence depicted is described in the text. Bar markers represent $100 \mu \mathrm{m}$.

ture sensitivity (Fig. 3). At $15^{\circ} \mathrm{C}$, NC-4 development was retarded and the early grexes became broad and bulbous, as seen in Ax-3 at $22^{\circ} \mathrm{C}$. At $27{ }^{\circ} \mathrm{C}, \mathrm{Ax}-3$ development was accelerated and led to narrow papillae and cylinders, resembling NC-4 grexes at $22^{\circ} \mathrm{C}$.

Light. NC-4 cells allowed to develop at $22^{\circ} \mathrm{C}$ under constant illumination with white light at $300 \mathrm{ft}$-candles ( $3250 \mathrm{~lx}$ ) showed early aggregation which was completed by approximately $10 \mathrm{~h}$ with the formation of hemispherical mounds. These acquired papillae and elongated to produce bulbous forms similar to those of the Ax-3 strain developed under standard (dark) conditions (see Fig. 2 E to I). 

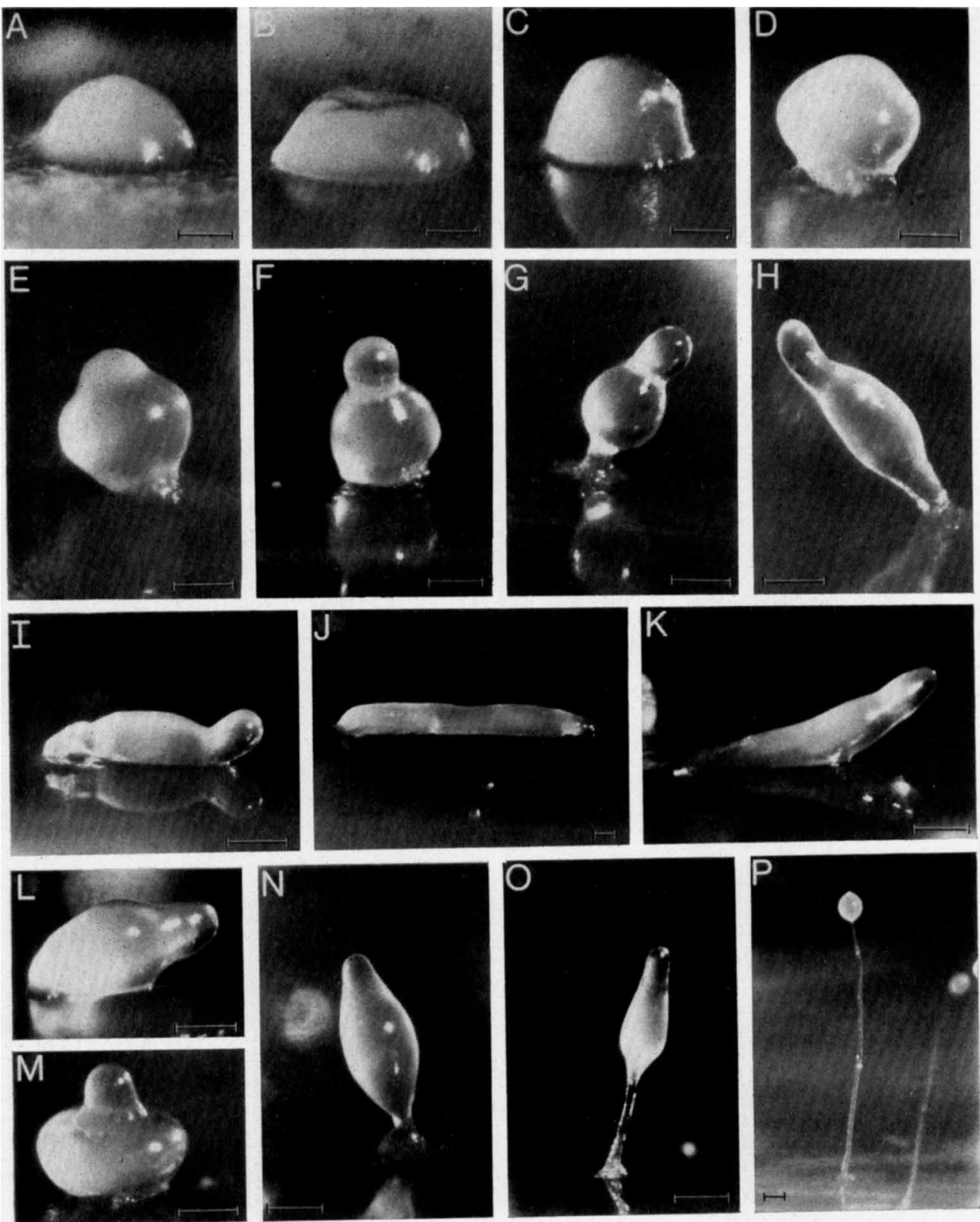

Fig. 2. Stages in the morphogenesis of the mutant strain, Ax-3. The temporal sequence depicted is described in the text. Bar markers represent $100 \mu \mathrm{m}$.

Plating density and perfusion of air. Development in sealed chambers and at high plating densities accentuated the aberrant morphogenetic pattern of Ax-3. For example, delay of Ax-3 in the mound stage was prolonged at $10^{6}$ cells $\mathrm{cm}^{-2}$, but was minimal at $10^{5}$ cells $\mathrm{cm}^{-2}$, at which plating density the phenotype more closely resembled NC-4. We ascribe these effects to volatile factors released into the atmosphere, since Ax-3 cells plated at high density but incubated in chambers flushed with fresh air at $100 \%$ humidity showed dramatically accelerated grex development until the sombrero stage where they accumulated. NC-4 grexes also accumulated in the sombrero stage when flushed with fresh humid air. 

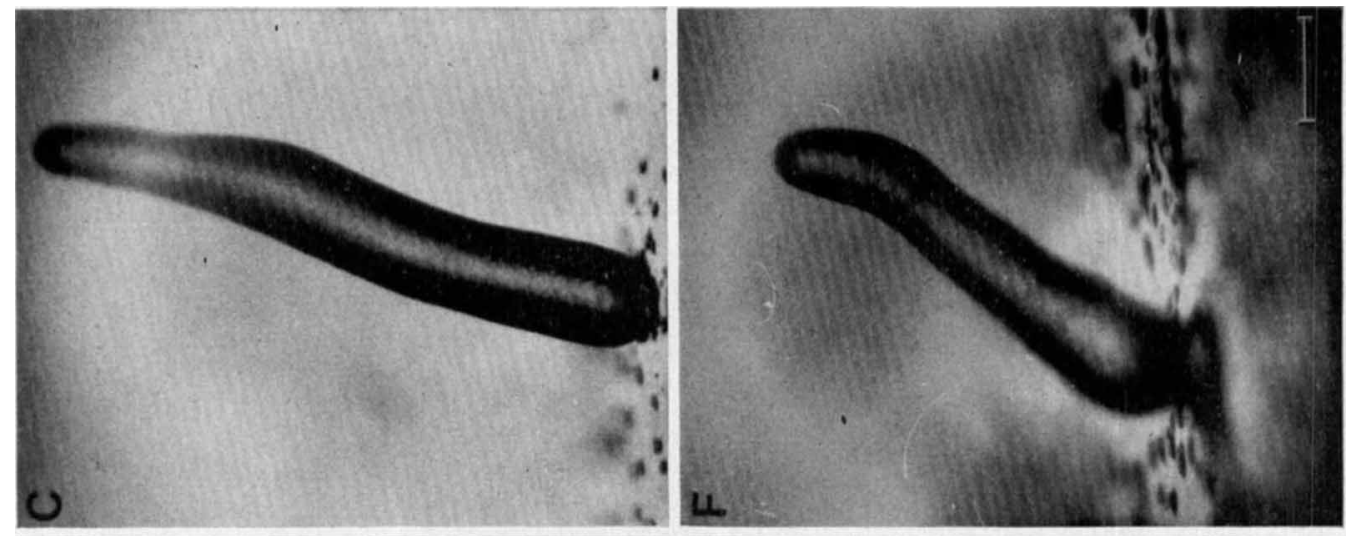

気

究 in

可

एँ

递

导

步

苞
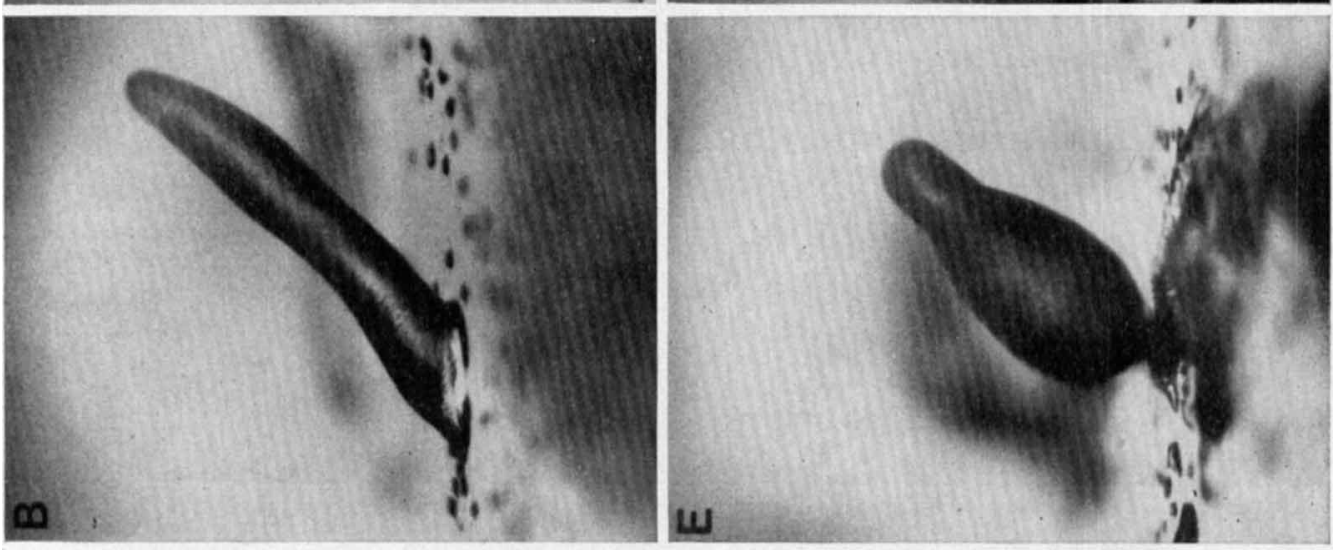

ᄂu

눙근

몽물

ไั้ก

일

ํํㅇㄱ

ㄴ.

这

ธ่ن

焉

泀

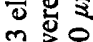

38

这舟

芯范
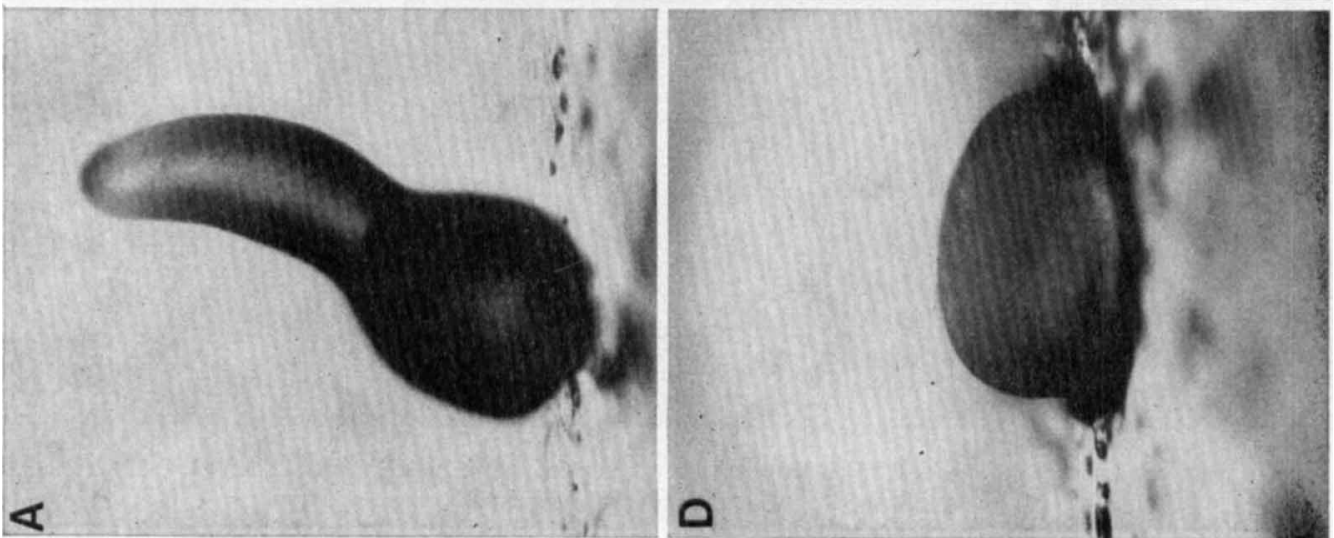

导导

Z范

宊

8

욜

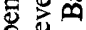

害定

인

츈

충현

氖

․ㅡㄹ

mi o

모 을 त 


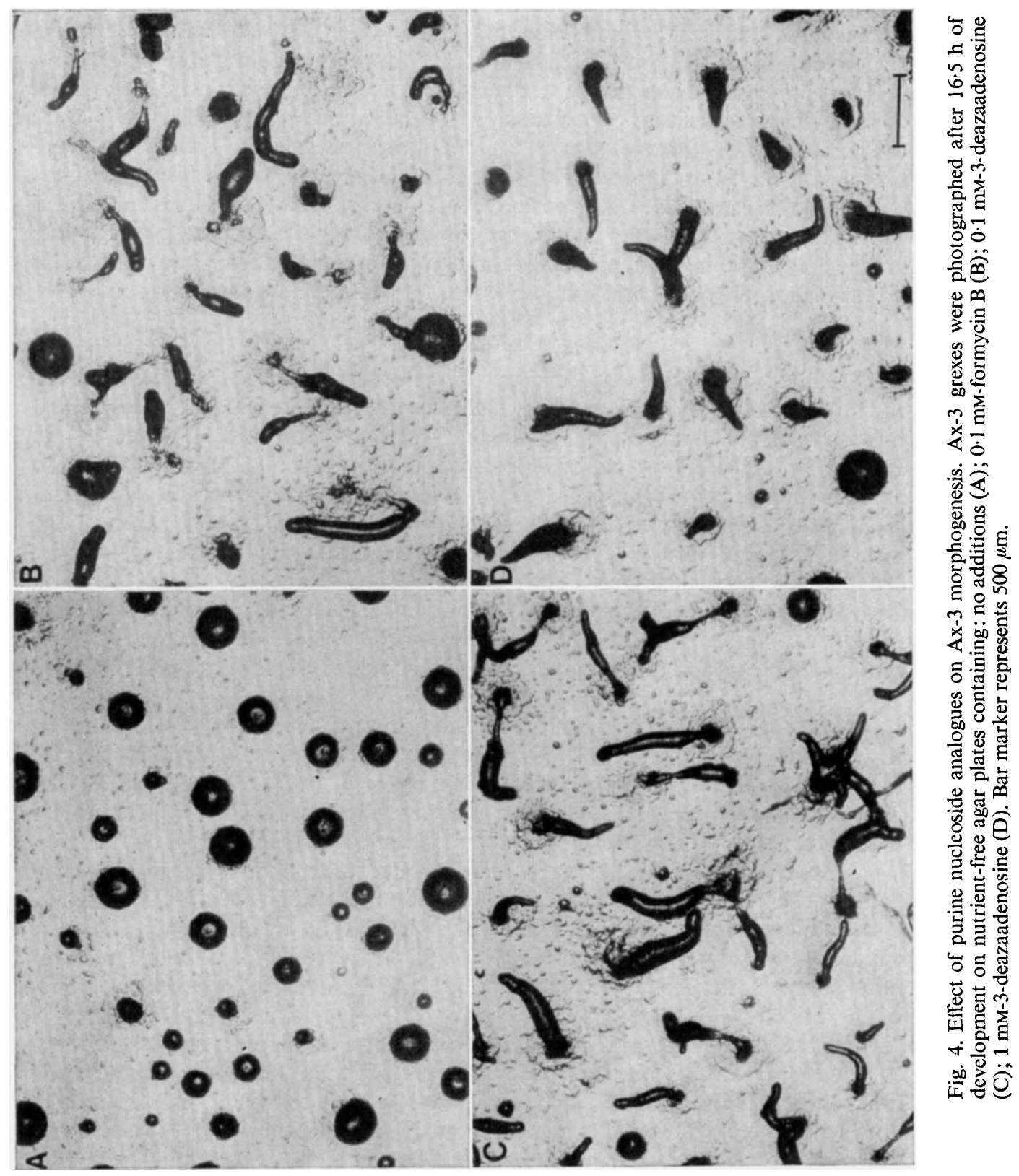


Purine nucleosides and their analogues. Various nucleosides incorporated into the substratum in nutrient-free agar plates influenced development. For example, $1 \mathrm{~mm}$-adenosine caused the delay of NC-4 aggregation by several hours, the delay of culmination by more than a day, and an increase in the territory size of Ax-3 by $150 \%$. The same concentration of inosine, guanosine or xanthosine had no effect.

Two nucleoside analogues, 3-deazaadenosine and formycin B, had dramatic effects. Formycin B has previously been shown to alter the choice of morphogenetic pathway in $D$. discoideum by causing fruiting grexes to revert to migrating slugs (Brackenbury et al., 1974). We found that Ax-3 grexes elongated by $14 \mathrm{~h}$ in the presence of $0 \cdot 1 \mathrm{~mm}-3$-deazaadenosine and by $16 \mathrm{~h}$ on $0.1 \mathrm{mM}$-formycin $\mathrm{B}$, whereas controls were still uniformly mounds (Fig. 4A, B, C). On $1 \mathrm{~mm}$-3-deazaadenosine, Ax-3 development closely resembled the NC-4 phenotype: neither stalks nor constrictions at the bases were evident, papillae were narrow and the grex contour was conical and not bulbous (Fig. 4D). Thus, these compounds accelerated Ax-3 morphogenesis and partially cured the Ax-3 abnormalities.

\section{NC-4/Ax-3 mixtures}

Cinemicrography of NC-4 and Ax-3 mixtures revealed that almost all the cells entered streams and migrated toward the nearest aggregation centre, with no evidence of differential migration (sorting out) of the two strains. This inference was supported by an analysis of plaques formed from the spores of individual sori constructed by $1: 1$ mixtures under conditions where no aberrant forms occurred (on Whatman 50 filter paper). Out of 72 sori examined, 70 gave the same differential in plaque morphology: $71 \pm 12 \%$ (S.D.) of the plaques were of the small variety characteristic of Ax-3 spores, while the remainder were large (NC-4 like). The preponderance of Ax-3 spores is probably due to greater cell division during starvation by Ax-3 since at low density we observed a $124 \pm 33 \%$ (S.E.M.) increase in cell number by $\mathrm{Ax}-3$ and a $17 \pm 4 \%$ (S.E.M.) increase by NC-4. Since there was no evidence of segregation among grexes, we conclude that NC-4 and Ax-3 co-aggregated indiscriminately.

Hybrid aggregates followed various morphogenetic patterns depending primarily on the substratum and the ratio of Ax-3 to NC-4. The extremes that were observed were: (1) synergism by equal mixtures on Whatman 50 filter paper; (2) torus formation with $3: 1$ Ax-3/NC-4 mixtures on agar; and (3) binary grex formation on Millipore filters. Under other conditions mixtures of these phenotypes were observed, as described below.

Synergism. Every stage of development occurred earlier in equal mixtures of NC-4 and Ax-3 on agar and particularly Whatman 50 filters than with either NC-4 or Ax-3 alone. For example, culmination in mixtures was nearly completed by $24 \mathrm{~h}$ while NC-4 grexes were still slugs and Ax-3 grexes were still mounds. Reducing the fraction of Ax-3 in the mixtures delayed culmination; however, the presence of as little as $2 \% \mathrm{Ax}-3$ accelerated the culmination of NC-4.

Torus formation. It has previously been reported that the annular centres of spiral aggregates resembling toruses are sometimes still present after the end of aggregation (Arndt, 1937; Raper, 1941; Bonner, 1950; Shaffer, 1957). We observed a different type of torus arising from the expansion of mounds formed from mixtures of NC-4 and Ax-3 (Fig. 5). Initially, a central depression appeared in these mounds, as is often seen in pure Ax-3. The depression deepened, forming a hole. The cellular annulus continued to expand over a period of hours forming a torus with only scattered cells and sometimes a node left in the centre (Fig. 5A, B, E).

Time-lapse cinemicrography demonstrated that cells in the toruses were in constant circumferential motion, causing them to rotate in either a clockwise or counter-clockwise direction. Within several hours, one or a few breaks appeared in the annulus. The cells on one side of the break continued to move circumferentially, building a node at that site (Fig. 5; and Clark \& Steck, 1979). These naturally occurring interruptions could be mimicked 

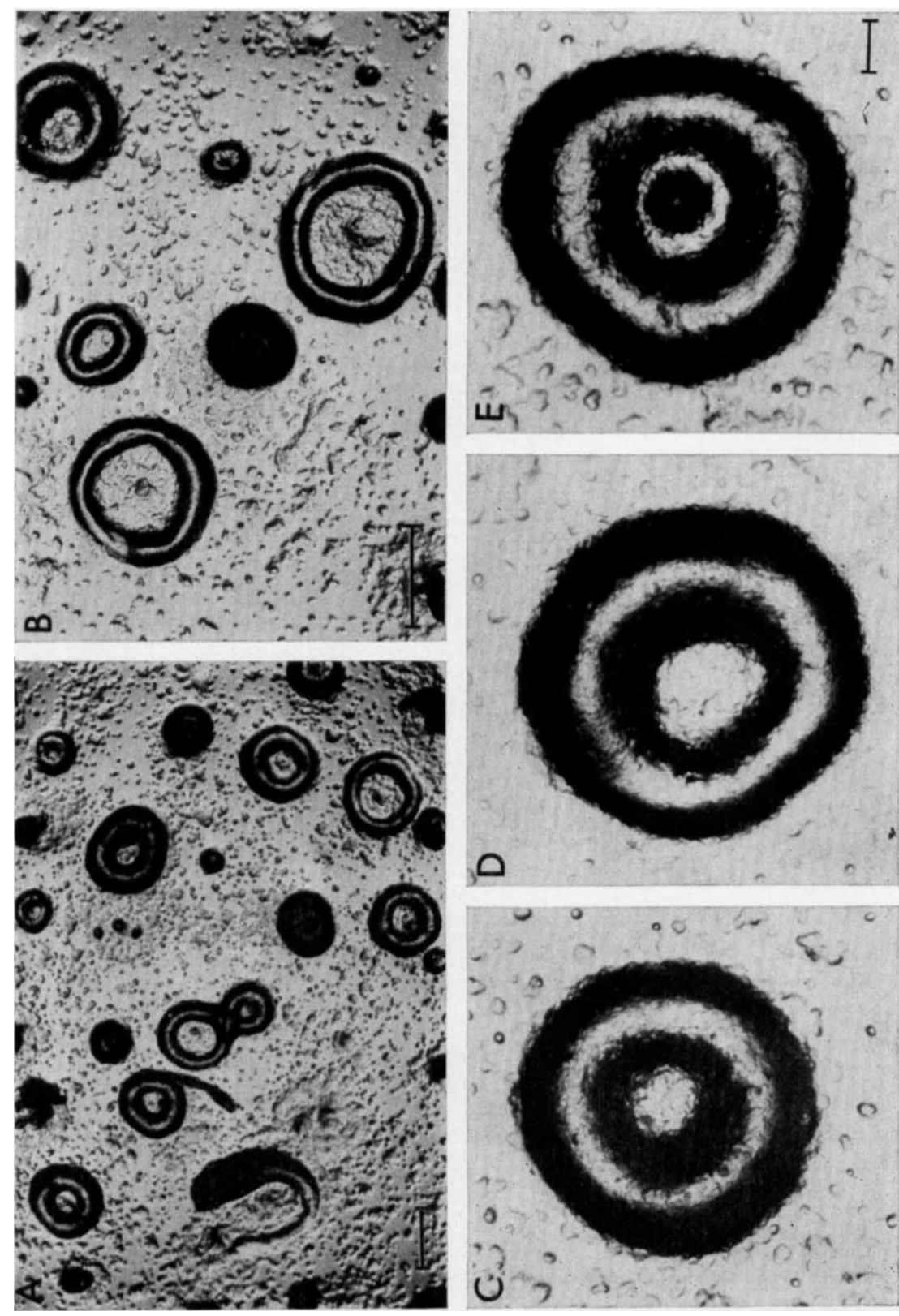

눈 速 鸟可 흥 훙 흘 웡 들. 온 톤 3 웅 응 응 윰 的 离원 열

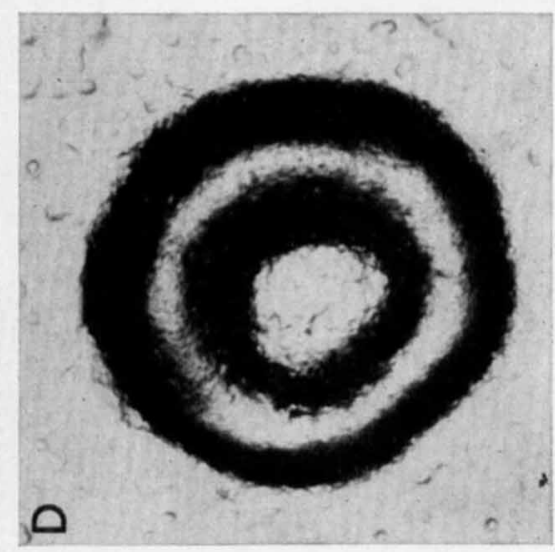
寸递 记豆 능 步 包

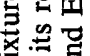
롱 외 है คํㅕㄴ 오요 을롤 $\because$ 눙호 멱홍응

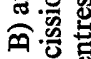
๑. $\checkmark$

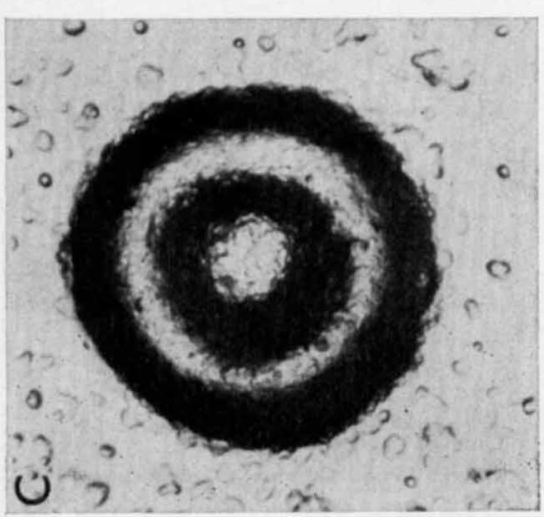

$\because \stackrel{0}{\circ}$. 就宫 䓃要要 원 安各。 这을 广可舟 乙咛回 ज立的

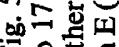
记옹․ㅡㅇ 


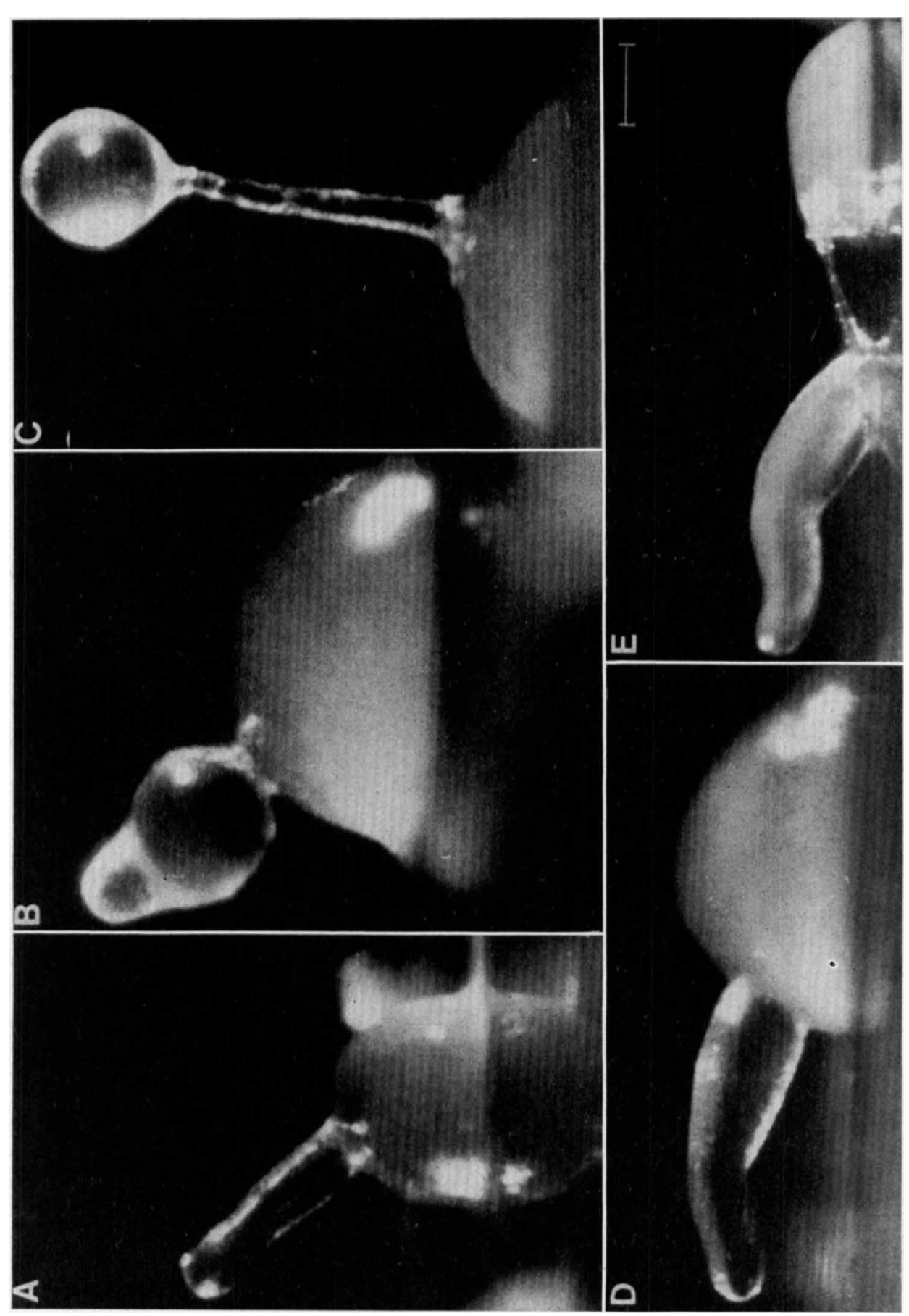

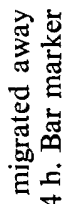

吾

О 画

๓ก

$\leq \frac{n}{2}$

을

$\Sigma \approx$

$\approx$ 요

ปิ

茟

$\stackrel{5}{\rightrightarrows=}$

商

要

的

这

范

。

焉

可

高

3 잉

突

这宁

跑

胥.

尊

文

$\leqslant$

广。

乙

$\because 7$

농

象

동

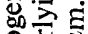

웡

릉을

$\sum$ 苛

$\circ$.

尘递 
by transecting the torus with a glass scalpel. The secondary mounds which formed sometimes repeated the cycle of torus formation and mound condensation several times. Usually, however, a papilla formed in the secondary mound, leading directly to elongation and slug formation. Culmination occurred after a brief period of migration.

The fraction of mounds which expanded into toruses varied with the NC-4 content of the mixture. The optimum of nearly $100 \%$ toruses usually occurred at 20 to $25 \%$ NC-4. Increasing the fraction of NC-4 in the mixture up to $50 \%$ increased the size of the toruses that formed, up to a maximum observed circumference of $4.2 \mathrm{~mm}$. It was not essential that the Ax-3 cells be grown in axenic culture: when Ax-3 cells grown on bacteria were mixed with $20 \% \mathrm{NC}-4$, toruses developed. However, mixtures of $80 \% \mathrm{Ax}-3$ cells grown axenically and $20 \% \mathrm{Ax}-3$ cells grown on bacteria did not form toruses. In addition, pure Ax-3 grexes formed toruses when exposed to $320 \mathrm{ft}$-candles $(3450 \mathrm{~lx}$ ) of light after 12.5 to $16 \mathrm{~h}$ development.

Other conditions were identified that influenced the proportion of grexes that formed toruses. Agar, particularly at $3 \%$, was more favourable for torus formation than a Millipore filter substratum, and both surpassed Whatman 50 filters. Torus formation was enhanced by development at $27^{\circ} \mathrm{C}$, inhibited at $15^{\circ} \mathrm{C}$, and favoured at high cell density $\left(10^{6} \mathrm{~cm}^{-2}\right)$. In addition, torus formation in $1: 3$ mixtures of $\mathrm{NC}-4 / \mathrm{Ax}-3$ was largely suppressed by $1 \mathrm{mM}-$ adenosine and totally suppressed by $0.1 \mathrm{~mm}$-3-deazaadenosine and $0.1 \mathrm{~mm}$-formycin $\mathbf{B}$; slugs formed instead. In the same experiments, toruses formed on plates containing no drug, $1 \mathrm{~mm}$-guanosine, $1 \mathrm{~mm}$-inosine or $1 \mathrm{~mm}$-xanthosine.

Binary grexes. When $1: 1$ and $1: 3$ mixtures of $\mathrm{NC}-4$ and $\mathrm{Ax}-3$ were plated on Millipore filters resting on agar, hemispherical mounds initially formed. However, unlike pure Ax-3, or mixtures on agar, these mounds frequently developed narrow finger-like papillae into which only a fraction of the cells entered. The rest of the cells remained in the hemispherical mound (Fig. 6A). The axially elongated portion ultimately either culminated into a normal fruiting body on the top of the mound (Fig. $6 \mathrm{~B}, \mathrm{C}$ ) or reclined and migrated away from the underlying mound leaving a thin trail of slime to mark its site of origin (Fig. 6D, E). The slugs that migrated away culminated early (by $20 \mathrm{~h}$ ). The underlying mounds were greatly delayed in their development, but eventually some culminated. Sori were harvested after $1 \mathrm{~d}$ of development from fruiting bodies which arose on top of mounds derived from $1: 3$ mixtures of NC-4 and Ax-3. None of the 1600 plaques from the 11 binary grex sori analysed were of the small Ax-3-like variety. It seems likely, therefore, that the upper, narrow structure in binary grexes was predominantly, if not totally, of NC-4 origin.

\section{DISCUSSION}

We can infer several important points about morphogenesis from our study of Ax-3 and Ax-3/NC-4 mixtures. First, many of our observations can be rationalized by the following paradigm: grexes become programmed either to form a slug or to fruit, but some aspect of the slug formation programme is also required for fruiting, thus normally imposing a sequential order of development. According to this paradigm, the abnormal behaviour of Ax-3 would be explained if Ax-3 prematurely expresses the fruiting programme and belatedly expresses the slug formation programme. Thus, Ax-3 grexes are delayed in the mound stage because they are competent to fruit but not to form a slug. As soon as the critical part of the slug programme is expressed, then the Ax-3 grexes prepare to fruit. Such a premature expression of fruitiness could cause the bulbous fruit-like morphology of the pre-slug Ax-3 grexes and the synergism shown by some mixtures of NC-4 and Ax-3, wherein NC-4 presumably provides the early slug-forming competency and Ax-3 the early fruiting competency.

We also infer that the outward movement of cells to form a torus is analogous to the outward movement of cells to form the brim of the sombrero. This analogy is supported by 
(i) the coincidence in Ax-3 of both the premature fruiting tendency and the tendency to form toruses, and (ii) the similar effects of altered conditions on the two processes. Both sombrero formation and torus formation are inhibited by development at $15{ }^{\circ} \mathrm{C}$ and the presence of adenosine, formycin B or 3-deazaadenosine, and both are stimulated by development at $27^{\circ} \mathrm{C}$ and the presence of light.

It has been proposed that ammonia and other factors released from cells govern the decision to form a slug or to fruit (Schindler \& Sussman, 1977 a; Sussman et al., 1978). Our results are consistent with this idea. Our observation of rapid transition of slugs to sombreros when perfused with fresh air supports the suggested role of ammonia as a slug-promoting factor. Our observation of blockage of fruiting in the sombrero stage by perfusing the air around the grexes could be due to either the removal of one of their 'fruit-inducing metabolites' (if it is also volatile) or by the removal of ammonia which is required for the differentiation of spores and stalk cells in submerged clumps (Sternfeld \& David, 1979).

All of these morphogenetic steps involve a transition in circumference of a circularly symmetrical structure, most strikingly the transformations from a mound to a slug and from a slug to a sombrero. Thus, all of these processes could be explained by a direct control by the cells over the circumference of the structures that they form. Our recent observations of circumferential cell movement in mounds, slugs and toruses have led us to propose an orbital hypothesis wherein cells would form loops sustaining an orbiting wave of cyclic AMP relay (Clark \& Steck, 1979). A few dominant loops would entrain neighbouring cells, thereby acting as organizers of tissue structure. The circumference of the loops would be determined by the relay properties of the constituent cells. Morphogenetic factors could then act by altering these relay properties. Ammonia has already been demonstrated to do so (Schindler \& Sussman, 1977b, 1979) in a manner consistent with its promotion of narrowcircumference grexes. These and the other observations reported here support this hypothesis.

We thank Peter Devreotes for helpful discussions, Anthony Robertson for the use of his cinemicrography equipment, Michael Potel for advice in statistical and computational methods, and Kenneth Tomchik for technical assistance. This research was supported by U.S. Public Health Service Grant GM 22321. R.L.C. was the recipient of a post-doctoral fellowship from the Anna Fuller Fund; T.L.S. was the recipient of a Faculty Research Award from the American Cancer Society.

\section{REFERENCES}

ARNDT, A. (1937). Untersuchungen über Dictyostelium mucoroides Brefeld. Wilhelm Roux' Archiv für Entwicklungsmechanik der Organismen 136, 681-747.

BONNER, J. (1944). A descriptive study of the development of the slime mold Dictyostelium discoideum. American Journal of Botany 31, 175-182.

BONNER, J. (1950). Observations on the polarity in the slime mold Dictyostelium discoideum. Biological Bulletin 99, 143-151.

BONNER, J. (1952). The pattern of differentiation in amoeboid slime molds. American Naturalist 86, 79-89.

BonNer, J. (1967). The Cellular Slime Molds, 2nd edn. Princeton, N.J.: Princeton University Press.

Brackenbury, R., Schindler, J., AleXander, S. \& Sussman, M. (1974). A choice of morphogenetic pathways in Dictyostelium discoideum induced by the adenosine analog formycin B. Journal of Molecular Biology 90, 529-539.
Clark, R. \& SteCK, T. (1979). Morphogenesis in Dictyostelium: an orbital hypothesis. Science 204, 1163-1168.

FrancIS, D. (1962). Movement of pseudoplasmodia of Dictyostelium discoideum. Ph.D. dissertation, University of Wisconsin, U.S.A.

Loomis, W. (1971). Sensitivity of Dictyostelium discoideum to nucleic acid analogues. Experimental Cell Research 64, 484-486.

Loomis, W. (1975). Dictyostelium discoideum. A Developmental System. New York: Academic Press.

Newell, P., Telser, A. \& Sussman, M. (1969). Alternative developmental pathways determined by environmental conditions in the cellular slime mold Dictyostelium discoideum. Journal of Bacteriology 100, 763-768.

RAPER, K. (1935). Dictyostelium discoideum, a new species of slime mold from decaying forest leaves. Journal of Agricultural Research 50, 135-147.

RAPER, K. (1940a). The communal nature of the 
fruiting process in the Acrasiae. American Journal of Botany 27, 436-448.

RAPER, K. (1940 b). Pseudoplasmodium formation and organization in Dictyostelium discoideum. Journal of the Elisha Mitchell Scientific Society 56, 241-282.

RAPER, K. (1941). Developmental patterns in simple slime molds. (Third Growth Symposium.) Growth $5,41-76$.

RAPER, K. \& FENNELL, D. (1952). Stalk formation in Dictyostelium. Bulletin of the Torrey Botanical Club 79, 25-51.

SChindler, J. \& Sussman, M. (1977a). Ammonia determines the choice of morphogenesis pathways in Dictyostelium discoideum. Journal of Molecular Biology 116, 161-169.

SChindleR, J. \& Sussman, M. (1977 b). Effect of $\mathrm{NH}_{3}$ on c-AMP associated activities and extracellular c-AMP production in Dictyostelium discoideum. Biochemical and Biophysical Research Communications 79, 611-617.

SChindler, J. \& Sussman, M. (1979). Inhibition by ammonia of intracellular c-AMP accumulation in Dictyostelium discoideum: its significance for the regulation of morphogenesis. Developmental Genetics 1, 13-20.

SHAFFER, B. (1957). Variability of behaviour of aggregating cellular slime moulds. Quarterly Journal of Microscopical Science 98, 393-405.

Shaffer, B. (1962). The Acrasina. Advances in Morphogenesis 2, 109-182.

SteRnFEld, J. \& DAVID, C. (1979). Ammonia plus another factor are necessary for differentiation in submerged clumps of Dictyostelium. Journal of Cell Science 38, 181-191.

Sussman, M. (1961). Cultivation and serial transfer of the slime mould, Dictyostelium discoideum, in liquid nutrient medium. Journal of General Microbiology 25, 375-378.

Sussman, M. (1966). Biochemical and genetic methods in the study of cellular slime mold development. Methods in Cell Physiology 2, 397-410.

Sussman, M., Schindler, J. \& KIM, H. (1978). Cell interactions controlling morphogenesis and gene expression in Dictyostelium. Birth Defects 14(2), 473-489. 